\title{
Impact of introducing low lift pump on improving income of farm households in some areas of Bhola district in Bangladesh
}

\author{
M. K. Majumder ${ }^{1}$ and M. S. Rahman ${ }^{2}$ \\ ${ }^{1}$ Department of Agricultural Economics, Sher-e-Bangla Agricultural University, Sher-e-BanglaNagar, Dhaka and \\ ${ }^{2}$ Department of Agricultural Economics, Bangladesh Agricultural University, Mymensingh-2202, Bangladesh \\ Email: monajoo3@yahoo.com
}

\begin{abstract}
This study focuses the impact of low lift pump (LLP) on farm income and cropping patterns followed by the selected farmers in Bhola district. A random sampling technique was used for the study. Primary data were collected from 60 LLP users from January to March, 2010 through two set of pre-tested questionnaires. Descriptive statistics and profit function were used in the study. Most of the farmers are well experience in farming. The average age of the household head is 47 for owner, 45 for tenant, 44 for owner cum tenant and 41 for LLP owners. The average educational level is 6 for owner, 4 for cash tenant, 5 for owner cum tenant and 5 for LLP Owners. Household size is the largest for cash tenant which is 5.36. Mug - Fallow - B.Aman was the main cropping patterns before using LLP and it was $39.22 \%$. On the other hand, Boro - Fallow -T.Aman was the main cropping pattern after introducing LLP and it was $53.22 \%$ in the study area. The income increased in all categories of farmers due to the introduction of LLP. Cash tenant earned more and owner cultivators earned less among the farmer's categories.
\end{abstract}

Keywords: Impact, LLP, Income, Farm households, Cropping pattern, Profitability

\section{Introduction}

Bangladesh, the most densely populated (993/sq.km.) country in the world has been suffering from food deficiency for a long time. Food scarcity has remained the major challenge for the government since liberation (Independence, 1971) as it tries to increase food grain production to meet up the demands of the nation's growing population 1.39 percent per year (BBS, 2009). Rice is the staple food of Bangladesh. Therefore, the policies are highly biased to produce more and more rice by introducing modern technologies like fertilizer, seed, power tiller, pesticide, irrigation, cultivation methods, etc. (Rahman, 2008). Rice constituted about $90 \%$ of the total food grain production. Among the three types of rice aus, aman and boro; the boro rice alone contributed the highest share of total rice production since 1998-99 to date. In 2007/08, Boro rice contributes about 57.59 percent of total rice production in Bangladesh (BER, 2009). Therefore, increase of Boro rice production would be a significant possible way to overcome food deficiency in this country. Boro rice is produced in Rabi season (Dec/Jan-Apr/May) and it grows under irrigated condition. Thus, development of irrigation availability is playing a vital role in this regard. For this reason, irrigation has been recognized as a "leading input" for Boro rice production in Bangladesh. Irrigation in Bangladesh is necessary, as floods and natural calamities make rainfed crop very difficult and on the other hand, dry period rainfall and residual soil-moisture are not sufficient to supply the necessary moisture requirements for sustainable crop growth. Recently, the minor irrigation project largely covered the irrigation area. Total coverage of irrigation through all sources (surface and groundwater) in 2002/03 is estimated to have been around 4.8 million hectares which is projected to increase to 6.05 million hectares in 2008/09 (BER, 2009). There are two main sources of water in Bangladesh e.g. surface and ground water. Shallow tubewell (STW) and deep tubewell (DTW) are used for lifting groundwater and low lift pump (LLP) is used for using surface water. Because of saline under ground water can not use in the study area. Only surface water is used through Low Lift Pump (LLP) in the study area. There are no STW and DTW in the study area. Few of the previous studies on cropping patterns are available but there is no study in the Bhola district especially in the LLP impact.

Fallow-Fallow-Potato earned highest profit and Fallow - Fallow - Boro earned lowest profit in the haor areas (Paul, 2009). Area under forest has increased during 19881/81 to 1999/2000 while the areas under current fallow and cultivable waste land have decreased (Begum, 2003). Potato-HYV Boro - T.Aman (LV) earned highest profit and it was Tk. 26200 and Fallow - Jute - T.Aman (LV) earned lowest and it was Tk. 7369. Inclusion of potato would increase income and employment opportunity but inclusion of jute 
increase income and employment opportunity but decrease overall net profit (Karim, 2000). Potato-HYV Boro-T.Aman earned highest profit and T.Aman-Fallow-HYV Boro earned lowest profit in Bogra district. Inclusion of potato would increase income and employment opportunity (Hossain, 1996). The above discussed literatures shows cropping patterns in different areas under different irrigation systems but no one shows under LLP system especially in the costal areas. At this stage of irrigation in Bangladesh agriculture it is high time to evaluate the LLPs impact on cropping pattern. The broad objectives of the study are to examine the socioeconomic profiles of the LLP users and economics of cropping patterns in the different tenurial systems.

\section{Materials and Methods}

Methodology is an indispensible and integral part of any research. The reliability of any scientific research depends to a great extent on the appropriate methodology used in the research. This study was conducted to find out the impact of LLP on farm household's income and cropping patterns in three villages namely, Southfassion, Nilkomol and Ginnajor in Charfassion upazila under Bhola district. This study also examined the socioeconomic profiles of the LLP users and owners. This study was based on field level data. The primary data were collected by the survey method from three villages namely, Southfassion, Nilkomol and Ginnajor in Charfassion upazila under Bhola district. A random sampling technique was used for the study. Primary data were collected from 60 LLP users from January to March, 2010 through two sets of pre-tested questionnaires. Collected data were classified, tabulated and analyzed in accordance to the objectives of the study. Both tabular and statistical techniques were used in the study. To find out the impact of LLP "before and after" method was used in the study.

\section{Descriptive statistics}

Descriptive technique of analysis is generally used to find out the crude association or difference between two variables. In this study descriptive technique was used to illustrate the whole picture of analysis. The sum, mean gross returns etc. of this technique is based on arithmetic average.

\section{Profit function}

In this study, simple profit equation was used for calculating profitability of cropping patterns.

$\Pi=\sum P 1 i Q 1 i+P 2 i Q 2 i-T C$

Where, $\mathrm{P} 1 \mathrm{i}=$ Price of main product

Q1i= Quantity of main products

$\mathrm{P} 2 \mathrm{i}=$ Price of by product

Q2i= Quantity of by products

$\mathrm{TC}=$ Total Cost

\section{Results and Discussion}

\section{Socioeconomic profiles of the LLP users}

Bangladesh is one of densely populated countries in the world, but in terms of economic condition; however, it is one of the developing countries in the world. In Bangladesh, per capita income is about Tk. 4400 which is relatively low compared to other countries. People differ from one another in many aspects. Behavior of an individual is largely determined by his/her characteristics. Socioeconomic characteristics of the farmers affect their production patterns. However, for the present research, a few of the socioeconomic characteristics have been taken into consideration for discussion in brief.

\section{Age distribution of the sample farmers}

In the study, family size (members) has been defined as total number of persons living together and taking meals from the same kitchen under the administration of the same head of the family. 
Table 1. Age distribution of the respondents

\begin{tabular}{|l|c|c|c|c|c|c|}
\hline \multirow{2}{*}{ Age of sample farmers } & \multicolumn{6}{|c|}{ Categories of farmers } \\
\cline { 2 - 7 } & \multicolumn{2}{|c|}{ Owner } & \multicolumn{2}{c|}{ Cash tenant } & \multicolumn{2}{c|}{ Owner cum cash tenant } \\
\cline { 2 - 7 } & No. & $\%$ & No. & $\%$ & No. & $\%$ \\
\hline Less than 30 years & 3 & 10.00 & 4 & 13.33 & 1 & 7.15 \\
\hline 30-40 years & 4 & 13.33 & 5 & 16.67 & 3 & 21.43 \\
\hline 41-50 years & 17 & 56.67 & 16 & 53.33 & 7 & 50.00 \\
\hline 51 years and above & 6 & 20.00 & 5 & 16.67 & 3 & 21.43 \\
\hline Total & 30 & 100 & 30 & 100 & 14 & 100 \\
\hline
\end{tabular}

Source: Field survey, 2010

Table 1 revealed that about 50 percent respondent of sample farmers belong to 41-50 years age bracket. Less than 30 years category was quite small among the categories and it was $10 \%$ for owner cultivators, $13.33 \%$ in cash tenant, $7.15 \%$ in owner cum cash tenant and $16.67 \%$ for LLP owners. In case of $30-40$ years age bracket it was about $15 \%$. In the last age bracket, it was also the same i.e. around $20 \%$.

\section{Educational status of the respondents}

Education was defined as the ability of an individual aged above 6 years to read and write or formal education received up to a certain standard. The government and various organizations placed greater emphasis and extend special facilities (like free education, stipend etc) for increasing the literacy rate. Education helps a person to have day to day information about the modern techniques, production costs and also production in his field.

To examine the educational status of owner, owner cum cash tenant and cash tenant farmers, the educational status of the sample farmers were divided into five categories. These were (i) illiterate; (ii) signature ability only; (iii) Primary level (class I-V); (iv) secondary level (VI to X); and (v) above secondary level of education. Those who cannot put signature, read and write were considered as illiterate. Table 2 displays the educational levels of the owner, owner cum cash tenant and cash tenant farmers.

Table 2. Educational status of the sample farmers

\begin{tabular}{|c|c|c|c|c|c|c|c|c|}
\hline \multirow{3}{*}{$\begin{array}{l}\text { Categories of } \\
\text { farmers }\end{array}$} & \multicolumn{8}{|c|}{ Level of education } \\
\hline & \multicolumn{2}{|c|}{ Illiterate } & \multicolumn{2}{|c|}{$\begin{array}{c}\text { Primary level } \\
(I-V)\end{array}$} & \multicolumn{2}{|c|}{$\begin{array}{c}\text { Secondary level } \\
(\mathrm{VI}-\mathrm{X})\end{array}$} & \multicolumn{2}{|c|}{$\begin{array}{c}\text { Above secondary level } \\
(\mathrm{XI} \text { - above) }\end{array}$} \\
\hline & No & $\%$ & No & $\%$ & No & $\%$ & No & $\%$ \\
\hline Owner & 1 & 3.33 & 10 & 33.33 & 15 & 50.00 & 3 & 10.00 \\
\hline Cash tenant & 5 & 16.67 & 21 & 70.00 & 4 & 13.33 & 1 & 3.33 \\
\hline $\begin{array}{l}\text { Owner cum } \\
\text { cash tenant }\end{array}$ & 2 & 14.28 & 6 & 42.86 & 4 & 28.57 & 2 & 14.28 \\
\hline All groups & 9 & 8.65 & 49 & 47.12 & 39 & 37.5 & 7 & 6.73 \\
\hline
\end{tabular}

Source: Field survey, 2010

This Table reveals that about 3.33, 16.67, 14.28 and 3.33 percent of owner, cash tenant, owner cum cash tenant and LLP owners respectively were illiterate having no formal or informal education. The cash tenant farmers were found to be illiterate than others. Owner, cash tenant, owner cum cash tenant farmers completing primary school (class- 1 to V) constituted 33.33, 70, 42.86 and 40 percent and about $50,13.33,28.57$ and 53.33 percent respectively had secondary level of education ranged from class six to ten. S.S.C passed student is greater in owner farmer, but very low in case of crop share tenant farmers. Again above secondary level education was higher (14.28 per cent) in case of owner cum cash tenant farmers where 13.33 percent in owner farmers. 


\section{Occupational status of sample farmers and family members}

There were a number of poor farmers in the study area. Agriculture was the main occupation of the selected heads of households in the study area. Besides agriculture, some farmers were engaged in other occupations like, business, services, day labors and others.

Table 3. Occupational status of the sample farmers

\begin{tabular}{|l|c|c|c|}
\hline Occupation type & Owner cultivators (30) & Cash tenant (30) & Owner cum cash-tenant (14) \\
\hline Main occupation & $23(76.67)$ & $24(80.00)$ & $12(85.71)$ \\
\hline i. Agriculture & $2(6.67)$ & $2(6.67)$ & $1(7.14)$ \\
\hline ii. Service & $5(16.67)$ & $4(13.33)$ & $1(7.14)$ \\
\hline iii. Business & $2(6.67)$ & $4(13.33)$ & $2(14.29)$ \\
\hline Secondary occupation & $6(20.00)$ & $1(3.67)$ & $2(14.29)$ \\
\hline i. Agriculture & $15(50.00)$ & $3(10.00)$ & $5(35.71)$ \\
\hline ii. Service & $4(13.33)$ & 0 & $1(7.15)$ \\
\hline iii. Business &
\end{tabular}

Source: Field survey, 2010

It was observed that agriculture was the main occupation for the all type of cultivators while LLP pump owners had pump operation. In case of owner cultivator, about 80 percent engaged in agriculture. In case of secondary occupation, business and agriculture occupies the highest percentage for cultivators and LLP pump owners, respectively (Table 3).

\section{Land holding patterns}

Land holding pattern means how available lands are distributed among different types of land. Own cultivated area is the highest in case of owner cultivator, owner cum cash tenant and LLP owners (Table 4 ). On the other hand, rented in area was higher for cash tenants compared to others. Pond and forest area are higher for owner cultivator and LLP owners, respectively.

Table 4. Land holding pattern of the sample farmers

\begin{tabular}{|c|l|c|c|c|}
\hline SI.No. & $\begin{array}{c}\text { Land holding type } \\
\text { (acres) }\end{array}$ & $\begin{array}{c}\text { Owner cultivators } \\
(30)\end{array}$ & $\begin{array}{c}\text { Cash tenant } \\
(30)\end{array}$ & $\begin{array}{c}\text { Owner cum cash } \\
\text { tenant (14) }\end{array}$ \\
\hline 1 & Homestead area & 0.316 & 0.254 & 0.295 \\
\hline 2 & Own cultivated area & 1.279 & 0.174 & 0.78 \\
\hline 3 & Rented in area & 0.888 & 1.26 & 0.651 \\
\hline 4 & Pond area & 0.24 & 0.194 & 0.213 \\
\hline 5 & Forest/fallow area & 0.087 & 0.10 & 0.100 \\
\hline
\end{tabular}

Source: Field survey, 2010

\section{Economics of cropping patterns}

A spatial and temporal arrangement of crops within a crop year largely is determined by the physical, biological and socio-economic factors. There are three usually cropping seasons (Rabi, Kharif-I or PreKharif, and Kharif-II) during a year in Bangladesh. Cropping patterns are important because we can understand how the lands are utilized through cropping patterns. The major different cropping patterns observed in the study area are given in Table 5. 
Table 5. Common cropping patterns in the study area

\begin{tabular}{|c|l|c|l|c|}
\hline SI. & \multicolumn{4}{|c|}{ Cropping Patterns } \\
\cline { 2 - 5 } No. & Before LLP introduced & Percentage & After LLP introduced & Percentage \\
\hline 1 & Mug-Fallow-B.Aman & 39.22 & Boro-Fallow-T.Aman & 53.22 \\
\hline 2 & Mustard-B.Aus-B.Aman & 21.56 & Boro-T.Aus-T.Aman & 20.21 \\
\hline 3 & Mustard-Fallow-B.Aman & 12.36 & Boro-Khesary-T.Aman & 8.99 \\
\hline 4 & Khesary-Fallow-B.Aman & 8.36 & Fallow-Fallow-T.Aman & 6.45 \\
\hline 5 & Fellow-Fallw-B.Aman & 4.51 & Fallow-T.Aus-T.Aman & 3.08 \\
\hline
\end{tabular}

Source: Field survey, 2010

It was observed that, Mug-Fallow-B.Aman was the main cropping pattern before using LLP and it was $39.22 \%$. On the other hand, Boro-Fallow-T.Aman was the main cropping pattern after introducing LLP and it was $53.22 \%$ in the study area. Other cropping patterns were Mustard-B.Aus-B.Aman, MustardFallow-B.Amam, Khesary-Fallow-B.Aman and Fallow-Fallow-B.Aman before using LLP. After introduction of LLP, the cropping patterns were Boro-T.Aus-T.Aman, Boro-Khesary-T.Aman, Fallow-Fallow-T.Aman, and Fallow-T.Aus-T.Aman.

Table 6. Cropping patterns for the owner cultivators

\begin{tabular}{|c|l|c|l|c|}
\hline SI. & \multicolumn{4}{|c|}{ Cropping Patterns } \\
\cline { 2 - 5 } No. & \multicolumn{1}{|c|}{ Before LLP introduced } & Percentage & After LLP introduced & Percentage \\
\hline 1 & Mug- Fallow- B.Aman & 48.22 & Boro- Fallow- T.Aman & 56.33 \\
\hline 2 & Mustard- B.Aus- B.Aman & 20.56 & Mug-T.Aus-T.Aman & 17.21 \\
\hline 3 & Mustard-Fallow-B.Aman & 11.58 & Boro-T.Aman-Khesary & 7.59 \\
\hline 4 & Khesary-Fallow-B.Aman & 8.36 & Mustard-Fallow-T.Aman & 6.45 \\
\hline 5 & Fellow-Fallow-B,Aman & 6.99 & Groundnut-Fallow-T.Aman & 3.89 \\
\hline
\end{tabular}

Source: Feild survey, 2010

From the above Table 6 it was found that, Mug-Fallow-B.Aman was the main cropping pattern of the owner cultivators before using LLP and it was $48.22 \%$. On the other hand, Boro-Fallow-T.Aman was the main cropping pattern after introducing LLP and it was $56.33 \%$ for owner cultivators.

Table 7. Cropping patterns for the cash tenants

\begin{tabular}{|c|l|c|l|c|}
\hline SI. & \multicolumn{4}{|c|}{ Cropping Patterns } \\
\cline { 2 - 5 } No. & Before LLP introduced & Percentage & After LLP introduced & Percentage \\
\hline 1 & Mug-Fallow-B.Aman & 41.22 & Boro- T.Aus- T.Aman & 49.88 \\
\hline 2 & Mustard-B.Aus-B.Aman & 19.91 & Boro- Fallow-T.Aman & 20.14 \\
\hline 3 & Mustard-Fallow-B.Aman & 15.36 & Boro- T.Aman- Khesary & 8.23 \\
\hline 4 & Khesary-Fallow-B.Aman & 7.88 & Mustard- Fallow-T.Aman & 6.45 \\
\hline 5 & Mug-Fallow-B.Aman & 3.89 & Fellow- T.Aus- T.Aman & 4.22 \\
\hline
\end{tabular}

Source: Field survey, 2010

Table 7 showed that, Mug-Fallow-B.Aman was the main cropping pattern of the cash tenant before using LLP and it was $41.22 \%$. On the other hand, Boro-T.Aus-T.Aman was the main cropping pattern after introducing LLP and it was $49.88 \%$ for cash tenants. 
Table 8. Cropping patterns for the owner cum cash tenants

\begin{tabular}{|c|l|c|l|c|}
\hline SI. & \multicolumn{4}{|c|}{ Cropping Patterns } \\
\cline { 2 - 5 } No. & Before LLP introduced & Percentage & After LLP introduced & Percentage \\
\hline 1 & Mug - Fallow - B.Aman & 44.39 & Boro - T.Aus - T.Aman & 48.22 \\
\hline 2 & Mustard - B.Aus - B.Aman & 23.54 & Mug - Fallow - T.Aman & 21.33 \\
\hline 3 & Mustard - Fallow - B.Aus & 14.22 & Boro - T.Aus - Khesary & 9.78 \\
\hline 4 & Khesary - Fallow - B.Aman & 7.55 & Mustard - Fallow - T.Aman & 6.77 \\
\hline 5 & Mug - Fallow - B.Aus & 4.65 & Groundnut - Fallow - T.Aman & 3.22 \\
\hline
\end{tabular}

Source: Field survey, 2010

\section{Profitability of different cropping patterns}

Profitability of different cropping patterns was calculated to find out the effect of LLP irrigation system in different tenure systems. It is important to know what cropping pattern earns more profit in the study area under different tenant systems. Tables 9, 10, 11 illustrate the profitability of different cropping patterns under different tenerial arrangements.

Table 9. Calculation of profitability in different cropping patterns for owner cultivators (Tk/ha/cropping pattern/yr)

\begin{tabular}{|c|c|c|c|c|c|c|}
\hline \multirow{2}{*}{$\begin{array}{l}\text { SI. } \\
\text { No. }\end{array}$} & \multicolumn{3}{|c|}{ Before LLP introduction } & \multicolumn{3}{|c|}{ After LLP introduction } \\
\hline & Cropping pattern & Net return & $\begin{array}{l}\text { Total } \\
\text { Return }\end{array}$ & Cropping pattern & Net return & $\begin{array}{l}\text { Total } \\
\text { Return }\end{array}$ \\
\hline CP1 & $\begin{array}{l}\text { Mug - Fallow - } \\
\text { B.Aman }\end{array}$ & $15202-0-14056$ & 29,258 & $\begin{array}{l}\text { Boro-Fallow- } \\
\text { T.Aman }\end{array}$ & $38764-0-19783$ & 58,547 \\
\hline CP2 & $\begin{array}{l}\text { Mug - B.Aus - } \\
\text { B.Aman }\end{array}$ & |15202-15059-14056 & 44,317 & $\begin{array}{l}\text { Mug-T.Aus- } \\
\text { T.Aman }\end{array}$ & 29178-19183-19783 & 68,144 \\
\hline CP3 & $\begin{array}{l}\text { Mustard - Fallow - } \\
\text { B.Aman }\end{array}$ & 8546-0-14056 & 22,602 & $\begin{array}{l}\text { Boro-T.Aman- } \\
\text { Khesary }\end{array}$ & \begin{tabular}{|l|}
$38764-19783-16943$ \\
\end{tabular} & 75,490 \\
\hline CP4 & $\begin{array}{l}\text { Khesary -Fallow - } \\
\text { B.Aman }\end{array}$ & $10255-0-14056$ & 24,311 & $\begin{array}{l}\text { Kheasry-Fallow- } \\
\text { T.Aman }\end{array}$ & 16983-0-19783 & 36,766 \\
\hline CP5 & $\begin{array}{l}\text { Fallow - Fallow - } \\
\text { B,Aman }\end{array}$ & $0-0-14056$ & 14,056 & $\begin{array}{l}\text { Groundnut-Fallow- } \\
\text { Aman }\end{array}$ & $12379-0-19783$ & 32,162 \\
\hline Total & \multirow{2}{*}{\multicolumn{3}{|c|}{$\begin{array}{l}\frac{134,544}{26,909} \\
\end{array}$}} & \multicolumn{3}{|c|}{271,109} \\
\hline Average & & & & \multicolumn{3}{|c|}{54,222} \\
\hline
\end{tabular}

Source: Field survey, 2010

In case of owner cultivators' average income increased due to the introduction of LLP in different cropping patterns. The average cropping pattern, income was Tk. 26,909/ha before the introduction of LLP but it was Tk. 54,222/ha after the introduction of LLP. Mug-B.Aus-B.Aman cropping pattern earned the highest return (Tk. 44,317/ha) before using LLP but Boro-T.Aman-Kheasry cropping pattern earned the highest (Tk.75,490/ha) after introducing LLP.

In case of cash tenant, total income was increased due to the introduction of LLP in different cropping patterns. The average cropping pattern income was Tk. 31,847/ha before the introduction of LLP but it was Tk. 60,441/ha after the introduction of LLP. Mug-Aus-B.Aman cropping pattern earns the highest return Tk. 45,897/ha before LLP introduction and after LLP introduction Boro-T.Aus-T.Aman cropping pattern earns the highest returnTk.60,441/ha. 
Table 10. Calculation of profitability in different cropping pattern for cash tenants (Tk/ha/cp/yr)

\begin{tabular}{|c|c|c|c|c|c|c|}
\hline \multirow{2}{*}{$\begin{array}{l}\text { Sl. } \\
\text { No. }\end{array}$} & \multicolumn{3}{|c|}{ Before LLP } & \multicolumn{3}{|c|}{ After LLP } \\
\hline & Cropping patterns & Net return (Tk.) & $\begin{array}{l}\text { Total Return } \\
\text { (Tk.) }\end{array}$ & Cropping pattern & Net return (Tk.) & $\begin{array}{c}\text { Total } \\
\text { Return (Tk.) }\end{array}$ \\
\hline CP1 & $\begin{array}{l}\text { Mug-Fallow- } \\
\text { B.Aman }\end{array}$ & $17203-0-15043$ & 32,246 & $\begin{array}{l}\text { Boro-T.Aus- } \\
\text { T.Aman }\end{array}$ & $\begin{array}{c}\text { 40865-20480- } \\
21290\end{array}$ & 82,635 \\
\hline CP2 & $\begin{array}{l}\text { Mustard-B.Aus- } \\
\text { B.Aman }\end{array}$ & $\begin{array}{c}10028-13651- \\
15043\end{array}$ & 38,722 & $\begin{array}{l}\text { Boro-Fallow- } \\
\text { T.Aman }\end{array}$ & $40865-0-21290$ & 62,155 \\
\hline CP3 & $\begin{array}{l}\text { Mustard-Fallow- } \\
\text { B.Aman }\end{array}$ & $10028-0-10543$ & 20,571 & $\begin{array}{l}\text { Boro-T.Aman- } \\
\text { Khesary }\end{array}$ & $\begin{array}{c}\text { 40865-20480- } \\
16931\end{array}$ & 78,276 \\
\hline CP4 & $\begin{array}{l}\text { Khesary_Fallow- } \\
\text { B.Aman }\end{array}$ & $11256-0-10543$ & 21,799 & $\begin{array}{l}\text { Mustard-Fallow- } \\
\text { T.Aman }\end{array}$ & $16079-0-21290$ & 37,369 \\
\hline CP5 & Mug-Aus-B.Aman & $\begin{array}{c}17203-13651- \\
15043\end{array}$ & 45,897 & $\begin{array}{l}\text { Fallow-T.Aus- } \\
\text { T.Aman }\end{array}$ & $0-20480-21290$ & 41,770 \\
\hline Total & \multicolumn{3}{|c|}{159,235} & \multicolumn{3}{|c|}{303,305} \\
\hline Avrage & \multicolumn{3}{|c|}{31,847} & \multicolumn{3}{|c|}{60,441} \\
\hline
\end{tabular}

Source: Field survey, 2010

Table 11. Profitability in different cropping patterns for owner cum cash tenants (Tk/ha/cp/yr)

\begin{tabular}{|c|c|c|c|c|c|c|}
\hline \multirow{2}{*}{$\begin{array}{l}\text { Sl. } \\
\text { No. }\end{array}$} & \multicolumn{3}{|c|}{ Before LLP } & \multicolumn{3}{|c|}{ After LLP } \\
\hline & Cropping patterns & Net return (Tk.) & $\begin{array}{c}\text { Total Return } \\
(\mathrm{Tk} .)\end{array}$ & \begin{tabular}{|l|} 
Cropping \\
patterns
\end{tabular} & Net return (Tk.) & $\begin{array}{c}\text { Total Return } \\
\text { (Tk.) }\end{array}$ \\
\hline CP1 & $\begin{array}{l}\text { Mug-Fallow-B. } \\
\text { Aman }\end{array}$ & $16055-0-14807$ & 30,862 & $\begin{array}{l}\text { Boro-T.Aus-T. } \\
\text { Aman }\end{array}$ & $\begin{array}{c}39149-20310- \\
19490\end{array}$ & 78,949 \\
\hline CP2 & $\begin{array}{l}\text { Mustard-B.Aus-B. } \\
\text { Aman }\end{array}$ & $\begin{array}{c}10028-12844- \\
14807\end{array}$ & 37,679 & $\begin{array}{l}\text { Mug-Fallow-T. } \\
\text { Aman }\end{array}$ & $31154-0-19490$ & 50,644 \\
\hline CP3 & $\begin{array}{l}\text { Mustard-Fallow-B. } \\
\text { Aus }\end{array}$ & $10028-0-12844$ & 22,872 & \begin{tabular}{|l|} 
Boro-T. Aus- \\
Khesary
\end{tabular} & $\begin{array}{c}39149-20310- \\
17931 \\
\end{array}$ & 77,390 \\
\hline $\mathrm{CP} 4$ & $\begin{array}{l}\text { Khesary-Fallow- B. } \\
\text { Aman }\end{array}$ & $9587-0-14807$ & 24394 & $\begin{array}{l}\text { Kheasry- Fallow- } \\
\text { T. Aman } \\
\end{array}$ & 17931-0-19490 & 37,421 \\
\hline CP5 & Mug-Fallow-B. Aus & $16055-0-12844$ & 28,899 & \begin{tabular}{|l|} 
Groundnut- \\
Fallow-T. Aman
\end{tabular} & 12379-0-19490 & 31,869 \\
\hline Total & \multicolumn{3}{|c|}{144,706} & \multicolumn{3}{|c|}{276,273} \\
\hline Average & \multicolumn{3}{|c|}{28,942} & \multicolumn{3}{|c|}{55,255} \\
\hline
\end{tabular}

Source: Field survey, 2010

It was observed from Table 11 that the total income increased due to the introduction of LLP in different cropping patterns. The average cropping pattern income was Tk. 28,942/ha before the introduction of LLP and was Tk. 55,255/ha after the introduction of LLP. Mustard-B.Aus-B.Aman cropping pattern earns the highest return (Tk. 37,679/ha) before LLP introduction and Boro-T.Aus-T.Aman cropping pattern earns the highest (Tk. 78,949/ha) after LLP introduction.

Among the three types of cultivators', cash tenant got the highest profit in different cropping patterns and owner cultivators got the lowest profit. It may be for the efficient use of land by the landless cash tenant farmers. Normally, tenant farmers are more efficient because they give more attention in cultivation and as it is cash payment system the tenant gets the ownership for one year and they use it very efficiently. On the other hand, owner cultivators' can not use their land efficiently because they cannot give more attention in cultivation. But it is clear that farm income increased in all categories of tenure system due to the introduction of LLP irrigation system. 


\section{Conclusion}

Socioeconomic conditions of the sample farmers are relatively poor. However due to introduction of LLP, cropping patterns has changed and farm income also being increased. The government and nongovernment organizations should come forward for the expansion of LLP so that farmers can have easy access to use it. The extension workers should disseminate the results to the farmers and policy makers. It may also be concluded that LLP creates a revaluation in the agricultural sector for achieving food security especially in the coastal areas.

\section{References}

BER. 2009. Ministry of Finance, Government of the People's Republic of Bangladesh, Dhaka.

BBS. 2009. Year Book of Agricultural Statistics of Bangladesh, Bangladesh Bureau of Statistics, Statistical Division, Ministry of Planning, Government of the People's Republic of Bangladesh, Dhaka.

Begum, R. 2003. Changes in land use pattern and cropping pattern of Bangladesh during 1980/81 to 1999/2000, M.Sc. Ag. Econ. Thesis, Bangladesh Agricultural University, Mymensingh.

Hossain, M.D. 1996. Relative profitability from alternative cropping pattern under irrigated condition in a selected area of Bogra district, M.Sc. Ag. Econ. Thesis, Bangladesh Agricultural University, Mymensingh.

Karim, M.A. 2000. Economics of some selected cropping patterns in Taragonj thana of Rangpur district, M.Sc. Ag. Econ. Thesis, Bangladesh Agricultural University, Mymensingh.

Khan, M.A.R. 2003. Performance of LLP and STW under farmer managed irrigation systems in Netrokona district of Bangladesh, M.Sc. Ag. Econ. Thesis, Bangladesh Agricultural University, Mymensingh.

Paul, G.C. 2009. Relative profitability and food security from alternative cropping patterns in some selected areas of Bangladesh, M.Sc. Ag. Econ. Thesis, Bangladesh Agricultural University, Mymensingh.

Rahman, M.S. 2008. How to Sell Water? M.S. Thesis, Norwegian University of Life Sciences, Norway. 